\title{
THE FIFTEENTH INTERNATIONAL CONGRESS OF ZOOLOGY
}

$I^{\mathrm{T}}$ was a happy choice of the Permanent Committee of International Congresses of Zoology to hold the Fifteenth Congress in London during 1958, the same year as the Darwin-Wallace centenary, and in addition the bicentenary of the publication of Linnæus's "Systema Naturæ", 10th edition, the starting point of modern zoological nomenclature. A total of 1,934 enrolments was received, and although approximately two hundred of these were unable to attend, the result was the biggest attendance of any Zoological Congress since they were started in Paris in 1889. The United States, with more than two hundred enrolments, provided the largest overseas contingent, closely followed by France, and there was a large party from the U.S.S.R.; more than sixty countries of the world were represented. The numbers present were much higher than had been anticipated and threw an extra burden on the officers responsible for making the arrangements for meetings, accommodation, excursions, etc. However, the officers, with $\mathbf{H}$. R. Hewer (secretary-general) and N. D. Riley (registrar), proved equal to any emergency. Registration of members and issue of Congress literature, badges, etc., started at noon on July 14. Each member received a copy of the sixth edition of "The Origin of Species" with a preface by Sir Gavin de Beer; and "Evolution by Natural Selection", comprising Charles Darwin's sketch of 1842 , his essay of 1844 , an introduction by Sir Francis Darwin (1909), Darwin and Wallace's original communication to the Linnean Society on July 1, 1858, the whole with a foreword by Sir Gavin de Beer.

The inaugural plenary session was held in the Royal Albert Hall, where, in the absence of the honorary president of the Permanent Committee, Prof. M. Caullery, whose death was reported during the Congress, the secretary-general, Prof. Louis Fage, introduced the president of the Fifteenth Congress, Sir Gavin de Beer. In his inaugural address, Sir Gavin referred briefly to the events of the past five years, and in particular to the position of the International Commission for Zoological Nomenclature, and paid a tribute to the valuable work of $\mathrm{Mr}$. Francis Hemming, honorary secretary of the Commission during the past twenty-two years, who on the grounds of ill-health had been compelled to offer his resignation. A colloquium had been meeting during the week previous to the Congress, for the purpose of concluding the revision of the Rules of Zoological Nomenclature. These had been discussed at every Congress since the foundation of the Commission at Monaco in 1892 , and especially at Paris (1948) and Copenhagen (1953), but a definitive text had not yet emerged. Sir Gavin stressed the necessity of this text being produced as soon as possible, in order to avoid the confusion of names that would inevitably result in its absence. He continued by emphasizing the value of congresses such as this where zoologists of all branches could meet and discuss their various problems, for there was a danger that, with the increase of specialization, workers might get so far out of touch as to be unable to profit from each other's progress. He also directed attention to the platform party, which included not only the officers and members of the permanent committee but also the members of the Darwin and Wallace families and the heads of the institutions having special associations with the lives of Charles Darwin and Alfred Russel Wallace.

Later in the morning the meeting became public and Sir Julian Huxley gave an inaugural lecture entitled "The Emergence of Darwinism". He first dealt with the development of evolutionary biology during 1858-72, when it was in full flower, until the 1890 's, when William Bateson began a reaction which lasted nearly twenty years. This was succeeded by the present phase of Neo-Darwinism in which the basic concept of natural selection is related to the facts of modern genetics, ecology and palæontology. He then developed his theory that man is the chief agent for the future of evolution on this planet, and by building on the foundations of Darwinism we could use the evolutionary concept in considering the history and future development of our species. A science of human possibilities was considered necessary to help in guiding the long course of psycho-social evolution that lay ahead.

The sectional meetings started that afternoon and continued until July 23. The programmes were arranged in twelve sections: general zoology; evolution, taxonomy and genetics; marine zoology; invertebrate zoology; vertebrate zoology; comparative physiology; embryology; parasitology ; cytology; ecology; animal behaviour; and zoological nomenclature.

An unprecedented number of papers had been presented for communication and many could only be 'read in title', but all those submitted by members of the Congress will be printed in the Proceedings. It is invidious to select any particular communication among the hundreds presented, but an exception must be made of a series of papers dealing with Neopitina galatheae and the Monoplacophora, comprising an account of the comparative anatomy of this very primitive molluse by $H$. Lemehe and $K$. $G$. Wingstrand, and molluscan phylogeny and prostomal inter-relationships in the light of Neopilina, both by $\mathrm{H}$. Lemche.

The programmes ranged over a very wide field: the communication of zoology; the conservation of Nature; the teaching of zoology; the ancestry of man; the physiological basis of sense perception; neurosecretion; hormones; new approaches in cytology; primate behaviour ; flight and migration in birds and insects; ecology and behaviour; to mention only a few of the topics discussed.

The meetings were held in the lecture rooms of the Imperial College of Science and Technology and the Memorial Hall of the Royal Geographical Society. The Reception Room and adjoining rooms in the Students' Union provided an extraordinary and valuable range of services.

The main social functions included receptions at the British Museum (Natural History); the Senate House, University of London; and the Zoological Society of London, in its gardens in Regent's Park; also a private reception by the Shell Petroleum 
Company. On Sunday there was an orchestral concert in the Royal Albert Hall in which all the items were associated with animals, and the composer of the overture "The Wasps" - Vaughan Williams - happens to be the grand-nephew of both Charles Darwin and his wife. There were also excursions to Down House, Juniper Hall and Whipsnade Park, in addition to long tours after the Congress.

The final plenary session began with two papers, the first by E. N. Pavlovsky on "Some Modes of Evolution of Infections and Parasitic Diseases", with special reference to work in the U.S.S.R. ; the second by $J$. Millot and J. Anthony, "Resultats actuels de l'étude du Coelacanthe Latimeria chalumnae Smith, dernier des Crossoptérygiens", comprising the first detailed account of the anatomy of this interesting archaic fish.

Sir Gavin de Beer then presented the recommendations of the Colloquium on Zoological Nomenclature and mentioned that, under present conditions, it is no longer possible to carry on the work of the Nomenclature Commission on an honorary basis. The International Trust for Zoological Nomenclature, now under the chairmanship of Lord Hurcomb, will have a paid secretary, Mr. R. V. Melville, with a secretarial staff, to undertake the heavy work involved in correspondence and publications. It is hoped that the revised rules of Zoological Nomenclature will be issued within six months.

Sir Gavin also submitted a resolution by Section I "That this widely representative meeting of zoologists from many nations participating in the Fifteenth International Congress of Zoology wishes to place on record in Plenary Session the great urgency of safeguarding the fauna and flora of the Galapagos Islands and welcomes the project, initiated by the International Union for the Conservation of Nature, for establishing on the Islands an International Biological Station for research and for assisting the Authorities of Ecuador in the task of conservation, and trusts that every support will be given by all concerned to the early and successful realization of this vital project".

The resolutions were passed with acclamation and it was then announced that the next Congress would be held in the United States during 1963. Various changes in the Permanent Committee were announced: Prof. J. G. Baer (Neuchâtel) was elected president in succession to M. Caullery (deceased); $P$. Pierre-Grassé (Paris), secretary-general in succession to L. Fage (resigned); C. F. A. Pantin (Cambridge) and B. Rensch (Münster), in succession to $\mathbf{E}$. Hindle and $\mathrm{A}$. Kühn (resigned); and representatives of four new countries were added, $P$. Sawaya (Brazil), M. B. Lal (India), T. Jaczewsky (Poland) and J. Uchida (Japan). The new Committee also includes V. d'Ancona (Padua), H. Boschma (Leyden), S. Horstadius (Upsala), A. R. Jorge (Lisbon), E. N. Pavlovsky (Moscow), G. G. Simpson (New York), R. Spärck (Copenhagen), V. van Straelen (Brussels) and E. Witschi (Iowa City), who continue to represent their respective countries.

With the words "Little bear now makes way for big bear", Sir Gavin de Beer introduced the new president of the Permanent Committee, the towering Prof. J. G. Baer, of Neuchâtel, who then addressed the meeting, thus concluding a very successful zoological congress. EDWARD HinduE

\section{THE NATIONAL VEGETABLE RESEARCH STATION}

\section{MEMBERS' DAY}

\begin{abstract}
$\mathrm{T}^{\mathrm{H}}$ HE founders' meeting of the National Vegetable Research Station Association took place at the Station at Wellesbourne on June 12. The Association, membership of which is open to anyone interested, aims to foster closer contacts between the research staff of the Station and all concerned with the various aspects of vegetable production in Great Britain. Members elected officers to manage the Association's affairs, and after the meeting the party made a tour of the Station, and members of the staff spoke about their work and demonstrated aspects of it in the field.

The Plant Breeding Section showed first-generation breeding material of spring cabbage obtained under a project to develop a dual-purpose variety, able to be used either for greens or as hearted cabbage. Also on view were the winter-hardy survivors of a number of lines of peas derived from crosses of the hardy maple type with some of the non-hardy commercial varieties. This work was being undertaken in an attempt to develop autumn-sown wrinkled varieties to extend the canning and quick-freezing season. Brief descriptions were given of work on the breeding of non-bolting bunching beet and disease-resistant lettuce, on the production of hybrid onions, and on the inbreeding of brussels sprouts.
\end{abstract}

The parts of the Pathology Section's work which were demonstrated were those dealing with parsnip canker, tomato stem rot (Didymella) and the Ascochyta diseases in peas. The natural resistance of parsnip varieties to canker was being tested; existing commercial varieties showed little or no resistance, but some new selections were promising. Members saw plots of outdoor tomatoes being prepared for fungicide tests on Didymella, following previous work showing that captan and maneb would greatly reduce the severity of attack. Other diseases being studied included big vein and botrytis diseases of lettuce, clubroot of crucifers, silvering of red beet and mint rust.

The Chemistry Section concentrated on aspects of its field work and several long-term experiments on the mineral composition of soil and plant, soil structure, and plant growth were shown. One of these experiments had made it clear that for crops like brassicas with a high nitrogen requirement, inorganic nitrogen was better than organic, and that no practical advantage was to be gained from splitting dressings of inorganic nitrogen. A nitrogen-phosphorus-potassium factorial experiment, now in its fifth year, showed that large differences in the responses of various crops to levels of phosphorus and 